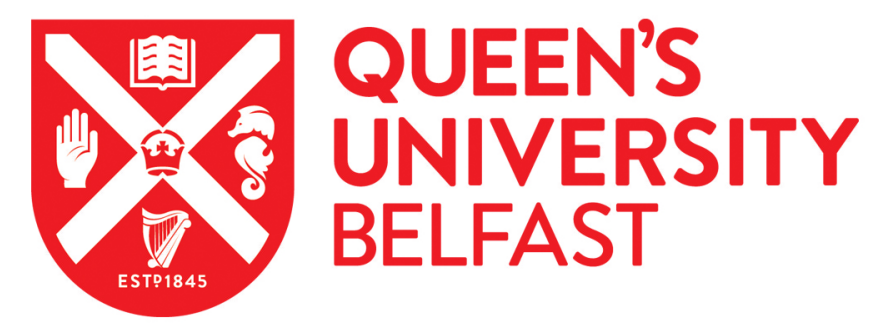

\title{
The eurozone crisis, German hegemony and labour market reform in the GIPS countries
}

Currie, D., \& Teague, P. (2017). The eurozone crisis, German hegemony and labour market reform in the GIPS countries. Industrial Relations Journal, 48(2), 154-173. https://doi.org/10.1111/irj.12173

\section{Published in:}

Industrial Relations Journal

\section{Document Version:}

Peer reviewed version

Queen's University Belfast - Research Portal:

Link to publication record in Queen's University Belfast Research Portal

Publisher rights

(C) 2017 Brian Towers (BRITOW) and John Wiley \& Sons Ltd. This work is made available online in accordance with the publisher's policies. Please refer to any applicable terms of use of the publisher.

\section{General rights}

Copyright for the publications made accessible via the Queen's University Belfast Research Portal is retained by the author(s) and / or other copyright owners and it is a condition of accessing these publications that users recognise and abide by the legal requirements associated with these rights.

Take down policy

The Research Portal is Queen's institutional repository that provides access to Queen's research output. Every effort has been made to ensure that content in the Research Portal does not infringe any person's rights, or applicable UK laws. If you discover content in the Research Portal that you believe breaches copyright or violates any law, please contact openaccess@qub.ac.uk. 


\title{
The Eurozone Crisis, German Hegemony and Labour Market Reform in the GIPS countries
}

\begin{abstract}
This paper argues that the Eurozone crisis has led Germany to act as the 'sovereign' for the Euro. An increasingly prominent feature of German hegemony over the Eurozone has been complete resistance to a genuinely European solution to the crisis. Instead, German political leaders have sought to make the Eurozone a more stable currency area by demanding far reaching labour market adjustment in the debtor countries of Greece, Ireland, Portugal and Spain, GIPS countries. In particular, they have demanded that these countries enact on the one hand stringent fiscal retrenchment polices and on the other hand wide ranging labour market flexibility programmes. This paper assesses why Germany's leaders elected to act as a coercive hegemon and examines the labour market reform pathways being travelled by GIPS countries. It argues that the austerity regime enacted under German hegemony has obliged the GIPS countries to introduce important labour market reforms. However, these reforms have not threatened the integrity of established national systems of industrial relations. As a result a Euro war of attrition has opened up between the European core and periphery which is a recipe for chronic economic and political instability inside the Eurozone.
\end{abstract}




\section{Introduction}

The global financial crisis that began in 2008 triggered an acute economic crisis within the Eurozone. Most notably, a number of Eurozone countries, in particular Greece, Ireland, Portugal and Spain - the GIPS countries - stood on the precipice of calamitous sovereign debt problems. Because of the financial and economic interdependencies that had been forged inside the Eurozone, the real prospect existed of the economic problems in the European periphery spreading to core member states, threatening in the process the very viability of the Euro (De Grauwe 2011). A decisive, comprehensive action plan was required to address the economic crisis yet serious shortcomings in the institutional design of the Eurozone hampered the construction of a genuinely European policy response. As a result, to avoid the potential meltdown of the Euro, the German government adopted a hegemonic role in the Eurozone. Under its leadership, a series of reforms have been made to the institutional architecture of the Eurozone to tighten surveillance of national level public expenditure, and at the same time the debtor member states have been obliged to enact a combination of fiscal entrenchment and labour market flexibility programmes (Streeck 2014). Thus, the price being paid to restore stability to the Euro has been the reorientation of European integration in a way that puts pressure on established industrial relations systems in most Eurozone countries but especially in the GIPS.

The purpose of this paper is to examine the fiscal retrenchment and labour market flexibility programmes that peripheral European countries have endured as a result of Germany becoming the hegemon of the Eurozone. The paper is organized as follows. The first section uses the varieties of capitalism literature to explain the nature of the Eurozone crisis. The following section discusses why Germany assumed the mantle of Eurozone hegemon and sets 
out the nature of this hegemonic role. Then the nature and scale of the fiscal retrenchment policies imposed on the GIPS countries is explained. The next section assesses the labour market flexibility initiatives implemented in the GIPS countries at the behest of the Troika, but ultimately sanctioned by Germany hegemony. The penultimate section evaluates the extent to which these reform programmes have uprooted established national industrial relations systems in the European periphery. The conclusions bring together the key arguments of the paper and discuss their significance.

\section{Understanding the Eurozone Crisis}

One of the main side effects of the Great Recession was to throw the Eurozone into economic turmoil. Numerous accounts have emerged about the nature of the Eurozone crisis, but perhaps the most convincing has been produced by those employing a 'varieties of capitalism' framework. On this view, the countries making up the Eurozone are institutionally heterogeneous, with the most marked divide existing between a group of 'coordinated' economies in northern Europe and a set of 'mixed market' economies in southern Europe (See Hassel 2014). A feature of the coordinated north European economies has been their ability to generate economic growth through successfully exporting tradable goods and services whereas the mixed market economies of southern Europe have traditionally pursued mostly demand-led or consumption-led growth strategies. For most of the 2000s, these contrasting growth regimes appeared to sit cheek-by-jowl in an untroubled manner as the Eurozone enjoyed healthy growth rates. But on closer examination institutional divergence was fueling persistent inflation differentials and rising current account imbalances between these two sets of countries (Boltho and Carlin 2013). 
The source of these economic imbalances were big capital flows from the core to the periphery inside the Eurozone: being successful export economies, meant that north European economies enjoyed large current account surpluses; banks in Germany and elsewhere awash with capital generated by these surpluses lent money to countries in the European periphery; a consumption-led boom followed in most of the European periphery. The scale of capital inflows from northern to southern Europe was such it created a Eurozone divided between creditor and debtor countries. The outbreak of the Eurozone crisis can be considered as the rapid unwinding of these culminated economic imbalances (Eichengreen 2014). Immediately, the institutional weaknesses of the Eurozone were laid bare. It became manifestly evident that no institutional process had been established when the single currency was created to monitor large intra-Eurozone capital flows and to take decisive action to reign in unsustainable borrowing by any member state. More importantly, it also became apparent that the Eurozone had no common shock-absorbing mechanisms such as a fiscal transfer arrangement to respond to the public and bank-debt vortexes that were threatening to escalate out of control. Thus the Eurozone crisis was existentialist in character as it threatened its very survival.

A group of born again Keynesians, their most vocal champion being Paul Krugman, the Nobel-winning American economist, strongly argued that plunging economic growth and rapidly increasing unemployment in the Eurozone could only be addressed through an aggressive Europe-wide expansionary fiscal policies designed to stimulate aggregate demand (Krugman 2013). But followers of the varieties of capitalism approach were unconvinced about the merits of Euro-Keynesianism, largely because it was seen as misdiagnosing the nature of the Eurozone crisis. In particular, the problems inside the Eurozone were considered to be the result of misguided efforts at housing different varieties of capitalism within a poorly designed monetary union (Hall 2016). Solving these deep-seated and structural flaws 
of the Eurozone was seen as beyond the reach of active demand management policies. From a varieties of capitalism perspective, the Eurozone had become entrapped in fairly intolerable economic and political conditions. Trying to undo the clear mistake of launching the Euro without an accompanying fiscal union by returning to separate national currencies was not considered feasible as it would create an even greater economic mess than the one already prevailing in the Eurozone (Offe 2014). Alternatively, seeking to address the crisis through creating a federal Europe so that a fully constituted supranational monetary union could be established was seen as blocked by the European integration process becoming entrenched in a 'spillback' dynamic: any attempt to deeper European integration seemed only to strengthen anti-European public opinion across the member-states (Hooghe and Marks 2009). Thus, the Eurozone could neither move backwards nor forwards as it sought to manoeuvre itself out of the crisis.

Iversen et al (2016) suggest that the infeasibility of large-scale political and economic reconstruction options to reboot the Eurozone meant that limited room existed for countries to escape the trap they had created for themselves. One possible pathway was the creation of some type of mutual gains bargain between northern and southern European countries which involved the periphery committing to a range of radical domestic reform and the core committing to debt relief. However, Iversen and Soskice (2013) suggest that the odds of any type of mutual gains bargain being concluded are very low not only because relations between the core and periphery are riven with mistrust but also because both have sharply different interests due to their economies being organized in radically contrasting ways. In the absence of any credible commitments to domestic reform by the periphery or debt relief by the core, the only other feasible scenario was for Germany to act as the hegemon for the Eurozone so to maintain order. But Iversen and Soskice (2013) do not see this as a pathway 
out of the Eurozone trap, but only a recipe for continuing austerity and economic misery as the periphery and core continually get embroiled in mini crises, battling each other over proposed reforms. Borrowing from game theory, the label this scenario the Euro war of attrition. In this situation, neither the core nor periphery has sufficient power to push through their own agenda, but have enough authority to veto the intentions of the other. Moreover, both sides are more interested in outlasting the other in the game rather than in reaching strategic compromises that would bring the game to an end.

Iversen and Soskice (2013) have creatively used the varieties of capitalist framework to produce an extremely sophisticated analysis of the current plight of the Eurozone. We agree with their assessment that Germany has become hegemon to the Eurozone and believe that labour market governance is one of the key battle sites where the Euro war of attrition is being fought out. Our interpretation is that Germany has been able to operate hegemonic power quite decisively inside the Eurozone and have obliged most of the debtor countries to introduce wide ranging reforms to their domestic economies, even though they have been reluctant to do so. All areas of economic management in the debtor countries have been touched by reform programmes imposed upon them. But perhaps it has been in the industrial relations arena where some of the most significant reforms have been introduced. However, we also believe that despite exerting considerable pressure on the periphery, German hegemony has not been unable to recast in any fundamental way the industrial relations systems of the debtor countries. These systems are rooted in long established social compromises and institutional arrangements and thus are difficult to dislodge. Just how the Eurozone periphery has been pressurized to reform their industrial relations systems by German hegemony will be explored in the remainder of the paper. But first it is necessary to 
explain why it was important for Germany to become a Eurozone hegemon and discuss what form this has taken.

\section{The nature of Germany hegemony of the Eurozone}

Before the creation of monetary union, a key characteristic of European integration was seeking to reconcile national sovereignty with the development of common EU policies. The creation of the Euro disrupted this broadly intergovernmental dynamic by injecting the need for a greater supranational component into the EU integration process. It is important to understand why this is the case. In departing from mainstream economics, which views money as a unit of account, a store of value, a medium of exchange and a standard of deferred payment, Aglietta and Orléan (1998) speak mostly about monetary systems, which they see as a lien social, a binding institution that ensures economic and social order. On the

one hand, a monetary system must generate sufficient confidence and trust in the wider economic system to allow the vast scale of everyday market transactions to occur relatively painlessly. On the other hand, it reduces the potential for serious social conflict by underwriting the terms of multiple social compromises - between creditors and debtors, labour and capital and so on. If a money system did not act as a lien social, the outcome would be social and economic disintegration, what Aglietta and Orléan (1998) call fractionnement. However, a money system acting as a lien social does not emerge spontaneously, this role only gains widespread acceptance when it becomes an integral feature of the wider apparatus of state power. Thus, for Aglietta and Orléan (1998) the creation and proper functioning of a monetary system is part and parcel of the exercise of political sovereignty - hence the notion of money as sovereignty (Grahl 2000). 
Aglietta (2012) argues that the dangers of fractionnement were present from the very outset with the creation of the single currency as the link between national monetary systems and national sovereignty was severed without a new overarching sovereign being constructed for the Eurozone. What made the problem more acute was that the Eurozone does not constitute an optimal currency area, which requires a high level of flexibility, convergence and coordination between participating countries (Eichengreen 2014). When the financial crisis erupted in 2007 all the signs of fractionnement started to appear inside the Eurozone excessive public and private debt, failing banks and general economic stagnation. To avoid the meltdown of the Euro and possibly even the entire EU, a sovereign needed to be created for the Eurozone. But as Soskice at la (2016) have noted the option of creating a federal Europe to allow a European solution to the Eurozone crisis was effectively blocked due to the malaise in the European integration process: the prevailing strong political attachment to national identity across member states effectively ruled out the creation of a federal Europe to save the Euro.

As a result, the only other realistic way the Eurozone could gain a 'sovereign' was for Germany to act as hegemon (Aglietta 2014). Over the years, German governments have been committed and enthusiastic supporters of European integration yet at the same time they have gone to great lengths to prevent other member states thinking that they operated in a unilateral or dominant manner within the EU (Bulmer and Paterson 2013). Thus to act as hegemon for the Eurozone would be a complete departure from the country's well established political approach to European integration. Yet the outbreak of the economic crisis in 2008 forced the hand of the Merkel government on the matter: either it could stand back and allow the Eurozone to collapse or step forward and help save the Eurozone by acting as its hegemon (Paterson 2011). In deciding to act as hegemon, the German Government ensured that the 
Eurozone had a sovereign, but it also meant disrupting the established European integration dynamic of seeking to reconcile 'national' and 'European' process integration.

As the sociologist Ulrich Beck (2013) puts it:

The fact is that Europe has become German. Nobody intended this to happen, but, in the light of the possible collapse of the euro, Germany has 'slipped' into the role of the decisive political power in Europe.... The European Union has twenty-seven member states, governments and parliaments; it has its own Parliament, a Commission, a Court, a High Representative for Foreign Affairs, a Commission President, a Council President, etc., etc. But, thanks to its economic might, Germany has been catapulted by the financial crisis and the crisis of the euro into the position of the undisputed great power in Europe as a whole.

When a single dominant state within an economic or monetary area begins to articulate and enforce the rules of interaction amongst the participating members of the system it acquires the mantel of hegemon: the dominant country has the capacity to oblige other countries to follow a particular course of action which might not be in their short-run interests (Joseph 2002). The notion of hegemony is usually associated with the Marxist thinker Antonio Gramsci who uses the term to highlight that capitalist societies are sustained by the pervasive ideological dominance of ruling class values and beliefs. But the term has a different meaning in international political economy. In this literature, the main purpose of a hegemon is to ensure that participating countries with divergent economic preferences adhere to a common set of rules or conventions (Kindleberger 1973). In relation to a monetary system, the absence of either a hegemon or a sovereign is likely to result in free-rider problems: individual countries will be prone to following economic policies that prioritize their own economic preferences over those of other participating countries (Aglietta 2012). The role of the hegemon is to hold in check this propensity to pursue beggar-thy-neighbour policies by constraining the actions of participating countries. But securing stability and order is not costless - capturing the benefits of monetary stability may require countries to accept policies that are not in their immediate self-interest (Eichengreen 1996). In meeting the costs of maintaining the stability of a monetary system, a hegemon can either act in a benevolent or 
coercive manner (Snidal 1985). A benevolent hegemon effectively underwrites the costs of maintaining monetary stability itself. For example, if a country participating in the monetary system has to adopt policies that cut against its economic and political preferences then it might be compensated by receiving some form of side payment. Effectively a benevolent hegemon internalizes the negative externalities associated with maintaining order in a monetary system. It is widely recognized, for example, that the USA acted as the benevolent hegemon for the reconstruction of postwar Europe as it had the power and willingness to bear the required level of responsibility and burden of sacrifice.

A coercive hegemon acts in a quite different manner. In this scenario, the hegemon uses its dominant power to shunt the costs of maintaining the monetary area on to the smaller or less powerful countries. Although the smaller countries may still benefit from monetary stability, it is the hegemon which benefits disproportionately under this regime. But if the hegemon overloads the smaller countries with the burden of maintaining the stability of the monetary system, then the problem of defection arises as the smaller countries may calculate that it is no longer in their interests to participate, which could jeopardize the entire monetary system (Gowa 1989). It is possible for a hegemon to act in a benevolent and coercive manner simultaneously. In this situation, the hegemon covers some but not all the costs of maintaining monetary stability. The distribution of the costs of maintaining the monetary system will depend on the extent to which membership of the system is considered to be beneficial to the hegemon and the other countries respectively (Milner 1998). Whatever the distribution of costs, it needs recognizing that the hegemon is the dominant country within the monetary system, with the decisive capacity to shape the character of economic policies. 
When Germany - effectively the Merkel government - acquired the role of hegemon for the Eurozone, it faced the choice of acting in a benevolent or coercive manner. For the most part, the Merkel government has shied away from adopting a benevolent stance. German hegemony has been exercised mostly in a very defensive manner - it is not inspired by the will to reshape the European order, even though such reshaping is certainly taking place (Knuth 2014). Rather it is driven by a refusal to allow European developments to call into question Germany's own socio-economic system. German hegemony is being exercised in a manner that does not require the adaptation of domestic policies to the needs of the Eurozone as a whole (Newman 2015). As a result, the costs of adjustment to the economic crisis as well as the cost of making the Eurozone more credible is being shouldered by those most acutely affected the current economic turmoil. In other words, Germany has acted as a coercive hegemon.

Political considerations are the main reason why Germany has acted more as a coercive than a benevolent hegemon. To have acted as a benevolent hegemon, the Merkel Government would needed to have focused on developing common policies amongst Eurozone member states to address the economic crisis through a process of mutual accommodation (Blyth and Matthijs 2013). Germany would not have carried the full burden of increasing the stability of the Eurozone, but it would have had to contribute its fair share. Under a benevolent hegemonic regime, German would have taken national action to weaken key elements of its domestic economic strategy. In particular, it would have had to abandon its relentless drive for wage moderation and instead promote strong overall wage growth (Grahl 2015). An internal revaluation strategy of this kind would have allowed Germany with a huge current account surplus make a positive contribution to reducing macro-economic imbalances within 
the Eurozone. High pay settlements in Germany would also have boosted aggregate demand across the member states.

The Merkel government declined to travel the benevolent hegemonic pathway largely because it calculated that domestic political support for this action was absent (Hassel 2015). It was also reluctant to do so because the enactment of benevolent hegemonic policies would almost certainly have led to the sovereignty of the Eurozone being progressively embedded within a European framework: paradoxically, benevolent hegemony would have withered away German Europe (Beck 2013). The Merkel Government was unlikely to adopt a policy stance that simultaneously obliged it to make a bigger contribution to Eurozone stability and accept a diminished role in setting macroeconomic policy for the single currency (Young and Semmler 2011). Thus, a more coercive hegemonic stance was adopted by the German Government. In exercising hegemonic authority to revamp the institutional architecture of the Eurozone, the German administration was motivated by two key considerations. One was not to agree to any new arrangement that would commit German taxpayers to providing new open-ended fiscal transfers to other poorly performing parts of the Eurozone, most notably the GIPS countries. The other was a refusal to make substantial changes to Germany's restrictive macroeconomic stance (Jacoby 2014). The key consequence of this stance has been to disrupt the traditional dynamic of European integration based on an accommodation of national sovereignty and the collective European purpose. A new dynamic was created which permitted the European integration process to intrude continually into national sovereignty to ensure that domestic economic and social systems functioned in a manner consistent with Eurozone membership. Coercive hegemony replaced symbiotic Europe with surveillance Europe. 
Important institutional innovations have been made to the governance of the Eurozone as a result of the German Government acting as a coercive sovereign. A raft of reforms brought together within a recast 'European Semester' has been enacted to impose "responsible" fiscal and collective bargaining behaviour on Eurozone members (Scuhlten and Mueller 2014). These changes gave institutional expression to the rise of surveillance Europe locking the Eurozone into a restrictive macroeconomic stance by constraining the policy autonomy of member states on economic and social matters, including collective bargaining (Marginson 2015). The re-organization of the European semester suggests that under certain conditions Germany will sanction institutional change that leads to the centralization of powers inside the Eurozone. But it will only support change that protects Germany from any undesired changes in its internal economic regime.

German coercive hegemony has not only been concerned with building a contractionary macro-economic regime within the Eurozone, it has also focused on encouraging reform to national social systems, particularly in the GIPS that received bail-out finance to address sovereign debt problems (Armingeon and Baccaro 2012). Aimed mainly at making domestic labour markets more flexible, these reforms were seen as necessary for these countries to become more viable long-term Eurozone members. The Troika - the ad hoc tripartite committee consisting of the European Commission, the European Central Bank (ECB) and the International Monetary Fund (IMF) that was set up to oversee economic retrenchment in the GIPS countries in return for financial assistance - placed these reforms at the centre of its adjustment programmes. An IMF working paper systematically set outs the scope and nature of the flexibility initiatives demanded of the GIPS countries (Blanchard et al 2013). In particular, they would be required to launch a series of macro and micro-oriented labour market initiatives aimed at improving their economies' ability to withstand macro-economic 
shocks and to enhance the competiveness of firms. Policies that were to be introduced included diluting employment protection rules not just to promote the economy-wide movement of workers, but also to improve enterprise-level profitability by lowering the costs of managing internal labour markets. Other policies involved the reduction of social benefits and minimum wage levels as well as the re-organization and weakening of collective bargaining systems to make employee behaviour more responsive to the market conditions facing their employing enterprise and to make wages fluctuate in line with the level of demand for its output.

In demanding that GIPS countries implement policies designed effectively to uproot embedded industrial relations systems, the coercive hegemony approach followed by the Merkel administration was imposing upon them most of the burden of restoring credibility to the Eurozone. In no small measure, this coercive hegemonic regime involved the refraction of Germany's domestic labour market reform experience onto the European level (Newman 2015). For nearly two decades the German labour market has been steadily liberalized and wage setting progressively decentralized (Hassel 2014). This was due in part to the failure to extend established West German employment relations systems to either the public or the private sector in the former East Germany. However the same trend was powerfully reinforced by the policies of the Federal government. In particular, the Hartz reforms were introduced to reduce and limit access to unemployment benefits, promote fixed-term and temporary work by liberalizing agency work, and expand unskilled work by reducing employee social security contributions on low paid jobs (Krebs and Scheffel 2013). Although it was questionable whether these reforms were actually necessary, the German administrative and political elite justified the liberalization of the labour market as the price that needed to be paid for German unification (Scharpf 2014). The widely held belief that 
these labour market reforms were both necessary and successful helps to explain why the German government did not consider it outlandish or unreasonable to insist on GIPS countries implementing labour market flexibility programmes. It felt entitled to make substantial labour market restructuring a litmus test of the commitment of the European periphery to making the Eurozone more stable. Free market ideologies - ordo-liberal or neoliberal - were probably also influential (Sinn, 2013)

\section{Fiscal Retrenchment in the GIPS countries}

Thus for the GIPS countries, German coercive hegemony presented a policy menu of fiscal discipline on the one hand and labour flexibility programmes on the other. Unsurprisingly, the popular feeling in the GIPS countries was that the burden of making the Eurozone more stable was being imposed on the less prosperous, most vulnerable member states. For sure, it has to be recognized that these countries received hefty financial assistance from the Troika. Greece received a funding package of $€ 110 \mathrm{bn}$ in 2010 , followed up by another $€ 164 \mathrm{bn}$ in 2013 and a further $€ 87 \mathrm{bn}$ in 2015 ; Ireland $€ 85 \mathrm{bn}$; Portugal $€ 78 \mathrm{bn}$; and Spain $€ 100 \mathrm{bn}$. In return, the Troika demanded that the four countries commit to large-scale fiscal retrenchment principally by slashing public expenditure. Greece committed to reducing the public sector wage bill by cutting public sector employment by 150,000 between 2010 and 2015. Ireland pledged to reduce public expenditure by $€ 10$ billion between 2011 and 2014 and increase taxes by $€ 5$ billion in the same period, with a view to reducing public spending from 49 per cent to 36 per cent of GNP. Portugal agreed to cut public sector pay and pensions by 5 per cent in 2011 and then to freeze these for the two subsequent years; suspend public private partnerships; introduce substantial cuts in administrative spending in all government departments including education; and increase taxes, particularly VAT. Spain agreed to make 
cuts of 16.9 per cent in government departmental budgets, freeze public sector wages and enact large scale job losses in the public sector.

Thus across the GIPS countries the quid pro quo for receiving large financial assistance was the adoption of widespread measures aimed at reducing government expenditure (De Grauwe and Ji 2013). The consequences of these tough austerity programmes have been predictable enough. As Figure 1 shows, living standards declined immediately, with fiscal consolidation triggering a sharp fall in GDP growth across the GIPS countries. Greece has been the most acutely affected, with national income falling by over 20 per cent since 2008: austerity has shrunk the economy by a fifth. The picture has been less bleak since 2012 as economic contraction has abated. But the outlook in terms of economic growth is hardly rosy, with GDP levels nearly static in most countries. The only exception appears to be Ireland which has enjoyed a healthy increase in national output since 2014. The Irish exception is largely due to its extensive markets outside the stagnant Eurozone, in the UK and elsewhere (Regan and Brazys 2015). In the other GIPS, with next to no export markets outside the Eurozone itself, balance of payments adjustment could only take the form of reduced imports - brought about by collapsing incomes. The inevitable outcome of national income falling in all GIPS countries between 2009 and 2014 has been significant increases in joblessness. Unemployment rates now stand above 25 per cent in Greece and Spain, while the figures for Portugal and Ireland are still above 10 per cent, having been nearer 20 per cent a few years ago. Young people have suffered the most from the lack of job opportunities: youth unemployment stands at a shocking 53 per cent in both Spain and Greece, while the figures are 35 and 24 per cent respectively for Portugal and Ireland. In all these countries, including Ireland, emigration has provided a safety valve for labour market pressures. Unsurprisingly, 
all GIPS countries have experienced sharp falls in public sector employment due to the huge scaling back in Government expenditure.

Fiscal retrenchment has also triggered - as was intended - internal devaluation in most of the GIPS countries. Figure 2 shows that unit labour costs have fallen in all countries. This is due to falling wages rather than improved productivity, which in the short run can improve competitiveness, but does little to close the immense development gaps in the Eurozone. The price has been a sharp decline in living standards and soaring unemployment. The consequence of lower purchasing power and more joblessness is falling aggregate demand and national output, which tends to increase budget deficits and make the fiscal position of governments even more precarious. After now more than four years of these policies, the weight of public sector indebtedness relative to GDP has in fact increased, not only in the GIPS, but in the Eurozone as a whole.

Figure 3 shows that public debt has rocketed in the GIPS countries as a result of fiscal retrenchment - and now stands at 180 per cent of GDP in Greece. Thus, the adoption of internal devaluation programmes has pushed these economies into a 'bad equilibrium' in which output and employment are lost and with no evidence that they can be easily restored. One possible way to ease the pain of economic adjustment in the GIPS economies would be for north European countries to pursue internal revaluation strategies that essentially involve increasing unit labour costs by permitting generous pay settlements. Figure 2 indicates that unit labour costs have increased recently in Germany as German employers and policymakers have had to recognise the scale of the Eurozone imbalances; however the trend is also upwards in the GIPS countries so that the relative position of the two areas has remained for the most part unchanged. Overall, the richer northern member states have been unwilling to 
assist GIPS countries by pursuing internal revaluation programmes or some variant of them. Thus, fiscal retrenchment has created a debtors' prison for these economies.

\section{Labour Market Flexibility in the GIPS countries}

Side-by-side with implementing fiscal retrenchment, the GIPS countries were required to introduce labour market reforms. The rationale of these reforms was to use supply-side measures to address unemployment because any increase in aggregate demand was ruled out by the new adopted Eurozone-wide restrictive macro policy regime. Behind this policy was the belief that labour market rigidities were widespread in debtor countries causing economic sclerosis. The credibility of this view is compromised by the huge scale of informal employment in the peripheral countries, where millions of workers have no effective employment rights whatsoever and where the "privileges" of some public sector employees hardly constrain the power of employers as a whole over an under-employed workforce. However, the Troika viewed its task as not simply engineering deflation, but also triggering structural adjustment. The labour market flexibility programmes prescribed by the Troika and sanctioned by Germany hegemony are assessed below.

\section{Weakening collective bargaining systems}

Although collective bargaining systems in the GIPS countries display a variety of national institutional idiosyncrasies, they also share a number of common features; however it needs emphasizing that the Irish collective bargaining system stands apart in several significant respects from the other countries. Features of the collective bargaining systems in Greece, Portugal and Spain share a number of characteristics. First of all, they tend to have multilayered systems of wage bargaining, with sector level bargaining predominating over bargaining at national, occupational (national or local level) and company levels. Secondly, 
the coverage of collective agreements tends to be high, despite relatively low trade union density rates (Greece 24\%; Spain 16\%; Portugal $18 \%$ before the recession in 2008). High coverage is normally secured through the administrative extension of agreements to those firms not involved in the negotiations. Thirdly, some form of what is known as the favourability principle usually operates which stipulates that any firm level wage bargaining that takes place can only increase wages established by higher level collective agreements.

The Troika's structural programmes for these countries insisted on the radical reform of these institutional properties of collective bargaining. In Greece a host of reforms have been introduced to weaken sector level bargaining and strengthen firm-level pay setting. At the end of 2010 a series of legal reforms introduced an additional type of collective agreement - the special firm-level collective agreement (SFLCA) - that allows employers and employees to agree wages levels less favourable than those stipulated in sectoral collective agreements. Effectively, the law abolished the favourability principle associated with firm-level collective agreement and offered non-negotiating firms an opt-out from the administrative extension of collectively agreed wages. Further reforms enacted in 2012 terminated the metenergeia system, which allowed sectoral collective agreements that had reached the end of their time period to continue operating for six months In addition, individualized forms of bargaining on pay and working conditions were made legally permissible for the first time. Collectively bargained salary increases linked to the length of employment service were also suspended until unemployment would have dropped once again below 10 per cent (Koukiadaki and Kokkinou 2014).

A similar pathway was travelled in Portugal. A Tripartite Agreement concluded in 2012 (Compromisso para o Crescimento, Competividade e Emprego), and endorsed by both trade 
unions and employers, introduced a number of radical changes to the collective bargaining system (Távora and González 2014). Pay setting was decentralized from the sector to the firm level. Moreover, the routine practice of extending sector-level collective agreements to other firms in the same sector that did not participate directly in the wage bargaining process was curtailed (under the new measures, government was only permitted to extend agreements when the involved employers' associations employed more than 50 per cent of employees in a sector.) A series measures to decentralize collective bargaining was also introduced in Spain. In 2012, a newly elected Conservative Government introduced the Real Decreto Ley 3/2012, which contained a hefty catalogue of labour market flexibility initiatives (Picot and Tassinari 2014). A key part of the reform package was promoting macro-economic flexibility through decentralizing collective bargaining from the sector-level to firms (Molina and Miguélez 2013). In addition, the new law made it easier for firms to opt out of established collective agreements, enabling them for the first time to introduce unilaterally changes to work organization and working conditions: in other words, firms were given greater freedom to pursue internal flexibility measures. These collective bargaining reforms brought to an end the last vestiges of the national social pact system based on tripartite agreements involving trade unions, employers and government: the 2012 reform programme enraged the trade unions and made the social pact regime unviable.

The renowned social pact system in Ireland was also a casualty of the economic crisis, collapsing in 2009 when the Government refused to use the structures of social partnership to develop a consensus-based restructuring programme to address the mounting debt problems. However, unlike other GIPS countries, the Troika did not insist that Ireland introduce any radical reform of its collective bargaining system. To a large extent, this can be explained by a return to orderly decentralised wage bargaining after the collapse of the national system of 
social partnership, a development consistent with the country's Anglo-American industrial relations traditions. In the private sector, employers and unions concluded a 'protocol' to guide the return to firm-level pay bargaining. The protocol set down agreed principles of pay fixing, which included job retention and the preservation of competitiveness, and a procedure for conflict resolution. In the public sector, after a period of stalemate, both Government and trade unions came to the view in 2010 that it was in their mutual interest to conclude centralized collective public sector agreements so that industrial relations in the sector could be conducted in an orderly manner. Ever since some form of national public sector collective agreement has been concluded to ensure that pay setting was orderly. Thus in relation to collective bargaining reform, Ireland has stood apart from other GIPS in not being obliged to introduce changes that challenge established institutional arrangements.

\section{Relaxing Employment Protection Rules}

The Troika was equally insistent that as well as recasting their collective bargaining systems, GIPS countries needed to weaken employment protection rules to strengthen micro-level flexibility. Although employment protection legislation (EPL) in Greece is around the OECD average, significant legal reforms have been introduced to relax some of these rules. First of all, the notice period prior to dismissal of white collar workers was substantially reduced: for those on long tenure, it has been shortened from 24 months to 6 months. The new legal provisions also lowered total severance costs for white collar workers with long tenure, in some cases by a half. Collective dismissals rules were also diluted to increase the threshold above which dismissals are characterised as collective. The probationary period in a job was extended from 2 months to 1 year and the use of fixed-term contracts was made easier. Legislative action was also taken to reduce overtime pay by 20 per cent across the board and to amend downwards pay for part time workers. Legal changes were also made to allow firms 
to introduce short time working and various forms of annualized working hours schemes (Papadimitriou 2013). Minimum wage levels have been significantly lowered. Yet further reforms were introduced aimed at reducing salary levels and scales as well as pension provision for certain categories of public sector workers. In addition, across-the-board changes were introduced to make working hours in the public sector more flexible (European Commission 2014a).

In Portugal, a series of reforms were introduced to encourage micro-level flexibility. Employment protection legislation that restricted the dismissal of individual employees was relaxed and levels of severance pay were reduced (Canas da Silva 2012). Under the old regulatory regime, individual dismissals were only possible when a work position became extinct due to the implementation of new technology. In addition, it was virtually impossible to dismiss employees who enjoyed 'seniority' status. Under the new regime, it became possible to dismiss individual employees for 'unsuitability' reasons irrespective of the introduction of new technology. The legal changes also reduced severance pay from 30 days to 20 days salary per year worked (approximately the EU average). In addition, for those signing new permanent contracts, severance payment was cut to 18 days for each of the first three years of the contract and 12 days for subsequent years. Regulation governing working time arrangements was also scaled back: in terms of overtime, employees were previously paid 50 per cent extra for the first hour worked, 75 per cent extra for additional hours and 100 per cent extra for overtime on holidays and Sundays. These rates were reduced to 25 per cent, 37.5 per cent and 50 per cent respectively. Further legislation encouraged firms to adopt annualized working schemes to reduce the need for overtime in the first place (Ramalho and do Rosário 2013). Legislation was also introduced that not only froze minimum wages until a 
full economic recovery but also shortened the duration and limited the amount of unemployment benefits.

Spain also introduced substantial reforms to its employment dismissal rules. A series of reforms in 2012 made it easier for firms to dismiss employees and reduced the monetary compensation employees received for unfair dismissal (European Commission 2014c). To reduce the incidence of informal employment, the 2012 reforms recommended for the first time that employers use written employment contracts when recruiting employees. The law also removed the need to obtain official authorization prior to proceeding with collective dismissals. Furthermore, it widened the reasons why individual employment contracts could be terminated. Severance pay was substantially cutback. Previously, dismissed employees were entitled to 45 days gross salary per year of employment up to a maximum of 42 month's salary. This was reduced to 33 days per year of employment and a cap was placed at 24 months.

Like in the area of collective bargaining reform, compared to other GIPS countries, Ireland did not come under anywhere near the same pressure from the Troika to deregulate its labour market. Indicative of the attitude adopted by the Troika was the reform of Registered Employment Agreements and Joint Labour Committees, statutory instruments to legally extend pay agreements in (mostly) low wage sectors. In its initial economic programme, the Troika signalled that these arrangements should be radically scaled back. But once it realized that Government had already initiated a reform of these bodies, it relaxed this demand and allowed the domestic reform to run its course. Overall, there was no noteworthy Governmentled labour market deregulation initiatives during the crisis (Roche et al 2013). To a large extent, the absence of labour market deregulation measures can be explained by the Irish 
employment system already being highly flexible. In other words, initial conditions separated Ireland from Greece, Portugal and Spain in that the Troika, for the most part, did not view the country as possessing institutional rigidities that required removal.

\section{Have national industrial relations systems been uprooted?}

There can be little doubt that the Troika imposed large scale fiscal consolidation and radical labour market flexibility programmes on the GIPS countries, although Ireland largely escaped the pressure to relax employment protection rules. The gentler treatment experienced by Ireland is largely due to the Troika believing it did not possess the segmented 'Mediterranean' employment systems that were considered so embedded in the labour markets of Greece, Portugal and Spain. A 'Mediterranean' employment system is widely seen - and not simply by the Troika - as dividing the labour market into 'insiders' and 'outsiders', with highly distortionary effects. Extensive employment protection for those on

permanent contracts is seen as leading to wage rigidity as insider employees become insulated from wider economic conditions (Bentolila et al 2010). Labour mobility, which facilitates economic adjustment from old to new economic activity, is considered impaired as insider employees stay with their existing employees. Training too is seen to be harmed as firms have little incentive to upskill employees on temporary contracts and employees on these contacts have little motivation to engage in training (Cabrales et al 2014). Finally, labour market dualism makes it difficult to integrate young people properly into work (Bentolila et al 2012).

The concerted drive by the Troika, as the representative of Germany hegemony, to disrupt insider/outsider labour markets is motivated by a desire to create national industrial relations systems that are compatible with monetary union in Europe. To move closer towards an 
optimal currency area, the Eurozone needs its institutionally heterogeneous national employment systems to function in a manner that ensures the alignment of wage with productivity growth as well as wider labour market adaptability. Insider/outsider labour markets are considered to do neither and thus contribute to macro-economic asymmetries inside the Eurozone by aggravating real exchange rate misalignments between core and periphery members.

Thus, German coercive hegemony has led to important work and employment reforms being introduced by GIPs countries. These reforms appear to be having a greater impact on some GIPS countries than others. It is difficult to argue that the Troika's labour market programme has uprooted established industrial relations systems in Ireland. Although the country has undergone a serious bout of internal deflation, which delivered a knock-out blow to the 18 year regime of social partnership, the Troika's austerity regime has left the country's industrial relations rules and traditions more or less intact. To a large extent, this can be explained by Ireland's fairly rapid, if still not complete, economic recovery and the fact that Irish labour markets were already deregulated, especially in comparison to other GIPS countries. In contrast to Ireland, Greece has experienced far reaching changes to its industrial relations system. One estimate suggests that within a 3 year period more than 100 legal provisions were introduced to effect labour market change. It is probably accurate to say that these measures, in the context of massive and persistent unemployment, have has a significant impact on the institutional framework for wage setting and the employment regulation regime.

The experience of Spain and Portugal appears to lie somewhere between Ireland and Greece. In relation to Spain, there are mixed indications about the impact of the drive towards greater 
labour market flexibility. There are hints that reforms to the collective bargaining system may have made wage setting more responsive to broader economic conditions. However, it is difficult to know whether these changes are due to institutional change or bleak underlying macroeconomic conditions (OECD 2013). But weakening employment protection rules to reduce high levels of labour market segmentation so far appears to have had little effect (European Commission 2014c). Unsurprisingly, in response to the economic crisis, firms drastically reduced the number of employees on temporary contracts - making permanent employees redundant would have been much more complex and costly despite the regulatory reforms. When a glimmer of economic stability emerged in 2013 and 2014, firms once again started hiring. In 2013, it appeared that firms had started recruiting employees on permanent contracts: the OECD (2014b) estimated that 25,000 additional new permanent contracts were being created each month due to the 2012 reforms, largely among firms with fewer than 100 employees. However, a radically different pattern emerged in 2014 as the vast majority (91.9\%) of over 16.7 million new contracts signed during 2014, were fixed-term. As a result, the share of temporary employment in total employment once again reached $25.0 \%$. Thus, labour market deregulation does not appear to have decisively changed the recruitment behaviour of firms and as a result segmentation remains a feature of the Spanish labour market.

A slightly different picture emerges in Portugal when the impact of labour market flexibility programme is considered. The indications suggest that this programme has been implemented effectively and the first signs are emerging that it may be influencing labour market behaviour. Although, the proportion of employees on temporary contracts remains high, a substantial share of new jobs being created use permanent contracts, which hints at an improved balance between permanent and fixed-term contracts. The scale of collective 
bargaining has been dramatically affected, although it is uncertain whether this is to do with the economic crisis or the 2012 labour market reforms. In particular, the number of sectorlevel collective agreements fell from 172 in 2008 to 36 in 2012, while the number of extensions fell from 137 to 12 in the same period. Firm-level collective agreements also declined considerably. The number of employees covered by collective agreements collapsed from almost 1.9 million in 2008 to some 225,000 in 2014 (European Commission 2014b). Thus, the evidence suggests that the 2012 reforms has influenced labour market behaviour and outcomes. Yet, the level of change that has occurred appears not to have impressed some as an influential view is that more needs to done to liberalize the employment system even further (OECD 2014a).

Important legal and institutional labour market reforms have been made in GIPS countries, apart from Ireland, but most informed accounts suggest that these adjustments have not dismantled the established industrial relations systems. It would be too strong to say that Germany hegemony has been able to dislodge fully the institutional arrangements of 'Mediterranean' labour markets. The inertia of social compromises embodied in national industrial relations systems is the chief reason why German hegemony has been unable to engineer the transplanting of labour market flexibility arrangements into the GIPs countries. A sign that the labour market deregulation drive orchestrated by the Troika has been thwarted is that the OECD and others have been making demands for even more thoroughgoing labour market flexibility programmes. It is also a sign that the Euro war of attribution continues unabated: the pursuit of labour market liberalization in the periphery is not relenting yet there are no indications that industrial relations systems in any of the GIPS countries are being radically transformed. 


\section{Conclusions}

Germany is now established as hegemon of the Eurozone. As such, it has pursued a doublebarrelled coercive strategy in response to the crisis of the Euro. One side of the strategy is to encourage a series of institutional innovations, most notably the creation of a banking union and a new surveillance procedure to guide public expenditure in EU member states. The other has been to dislodge industrial relations systems inside GIPS countries in the hope that, increased aggregate demand having been ruled out in the new macroeconomic policy regime, cheaper labour might mitigate their unemployment levels. Both components of the strategy are failures. Deep and widespread fiscal retrenchment has been introduced in the GIPS countries, triggering significant levels of internal devaluation. Economic and social adjustment has been substantial and painful. More generally, there is a strong deflationary bias to the macro-economic strategies now pursued in all European capitals. Investment prospects are now so weak that interest rates are negative. With regard to institutional change in the labour market, the drive to weaken collective wage setting processes and employment regulation is having a telling, yet uneven, impact. Although these reforms are corroding mechanisms for employment protection and social solidarity, it is unlikely that they are dismantling root-and-branch established industrial relations systems.

It is hard to see how the developments engineered by German hegemony have enhanced the economic and political stability of the Eurozone. Some measures such as the creation of the banking union have reduced some institutional deficiencies inside the Eurozone, but as a currency area it still faces existential threats. Economic structures, performance and policymaking across member states are more divergent than ever. In fact, under German coercive hegemony, the entire dynamic of European integration has been recast. It is no longer about seeking an accommodation between national sovereignty and the Europe purpose. Instead, it 
is about constraining autonomous national economic and social action so that it is in line with the imperatives of Eurozone. Ironically, the consequence has been to make the Eurozone a more asymmetrical currency area. An alarming polarization has emerged between creditor and debtor member states, between the European core and periphery (Iversen and Soskice 2013). Citizens in northern Europe feel the debtor countries brought their economic problems on themselves and thus must accept the hardships that come with economic and social consolidation. They fail to comprehend that a loan is a contract between two parties who bear joint responsibility for its outcome. In contrast, citizens in the European periphery resent the battery of regressive economic and social policies which are being imposed upon them from the outside in a highly undemocratic manner.

The result of this new dualism has been to open up a Euro war of attrition in the industrial relations sphere: spearheaded by Germany, a concerted drive has been launched to deregulate the labour markets of GIPS countries, but this effort has come up against the social embeddedness of national industrial relations systems in the European periphery. The result of this clash has been that the GIPS countries have been obliged to introduce important labour market reforms, but these appear not to have compromised the integrity of industrial relations systems as a whole. The irresistible force of the European core has meet the immovable object of the European periphery. The outcome of this stalemate is that political support for European integration has plummeted everywhere: the notion of the European project predicated on economic performance and social inclusion running in tandem lies in tatters. The only common ground that appears to tie the core and periphery together is the idea that unravelling the Eurozone would be an even greater calamity than its continuation. Thus, German coercive hegemony has brought the Euro short term relief, but its long-term stability is in no way assured. The incapacity of the member states to govern the Eurozone in 
a manner that is tolerable to all means that industrial relations systems everywhere within the EU, but particularly in GIPS countries are likely to remain under stress.

The only positive feature of German hegemony is that, so far, no decision has been taken either by the German government or by Commission leaders which would directly imperil the Union. As each new crisis erupts bad decisions or non-decisions are taken but the worst - a direct fragmentation of the Union - is somehow avoided - this is how, for example, the European Stability Mechanism was founded and other, innovative, crisis management measures, such as those adopted by the ECB, have found acceptance. It seems unlikely that this situation can continue for long. Either European construction will be seriously, perhaps irreversibly, impaired or a decision will have to be taken that certain other priorities - the existing policy regime in Germany, and/or the absolute primacy of the EU's competition rules, and/or the newly reinforced macroeconomic constraints - will have to give way. It is to be hoped that the European project will survive this coming trial. 


\section{References}

Aglietta, M. (2012) Zone euro: éclatement ou fédération, Michalon, Paris

Aglietta, M. (2014) Europe: sortir de la crise et inventer l'avenir, Michalon, Paris

Armingeon, K. and Baccaro, L. (2012) Political Economy of the Sovereign Debt Crisis: The Limits of Internal Devaluation, Industrial Law Journal 4: 3: 254-275.

Barreto and Naumann (1998) Portugal: Industrial Relations under Democracy, in Ferner, A. and Hyman, R. Changing Industrial Relations in Europe. Oxford: Blackwell

Beck U. (2013) German Europe, Cambridge: Polity Press

Bentolila, S, T. Boeri and P. Cahuc (2010), Ending the Scourge of Dual Labour Markets in Europe, Vox, 1 July 2010

Bentolila S. Dolado J. J. and Jimeno J. F. (2012) Reforming an Insider-Outsider Labor Market: The Spanish Experience, IZA Journal of European Labor Studies, Vol 1: 4:

Blanchard, O., Jaumotee, F. and Loungani, P. (2013) Labor Market Policies and IMF Advice in Advanced Economies During the Great Recession, IMF Staff Discussion Paper, March 29, 2013

Blyth M. and Matthijs M. (2011) Why Only Germany Can Fix the Euro, Foreign Affairs, Nov

Boltho, A. and Carlin, W. (2013) EMU's Problems: Asymmetric Shocks or Asymmetric Behavior? Comparative Economic Studies, Vol. 55: 3: 387-403

Bulmer S. (2014) Germany and the Eurozone Crisis: Between Hegemony and Domestic Politics, West European Politics, Vol. 37: 6: 1244-1263

Bulmer S. and Paterson, W. (2013) Germany as the EU's reluctant hegemon? Of economic strength and political constraints', Journal of European Public Policy, Vol. 20: 10: 13871405

Busch K., Hermann, C., Hinrichs, K. and Schulten T. (2013) Euro Crisis, Austerity Policy and the European Social Model How Crisis Policies in Southern Europe Threaten the EU's Social Dimension, Friedrich-Ebert-Stiftung, International Policy Analysis, Berlin.

Cabrales, A \& Dolado, J. J. and Mora, R., (2014) Dual Labour Markets and (Lack of) OnThe-Job Training: PIAAC Evidence from Spain and Other EU Countries, CEPR Discussion Papers 10246, C.E.P.R. Discussion Papers 
Canas da Silva, R. (2012) Portuguese Labour Law Reform: Developments in 2011-2012', European Labour Law Journal, 3

Currie, D. and Teague P. (2016) How does European integration influence employment relations?, in M Dickmann, C. Brewster, and P.R. Sparrow, Contemporary HRM Issues in Europe, London: Routledge

De Grauwe, P, (2011) The Governance of a Fragile Eurozone, CEPS Working Documents, Economic Policy, May

De Grauwe, P. and Moesen W. (2009), Gains for All: A Proposal for a Common Eurobond, Intereconomics, May/June.

De Grauwe P. and Ji Y. (2013) Panic-driven austerity in the Eurozone and its implications http://www.voxeu.org/article/panic-driven -austerity-eurozone-and-its-implications

Eichengreen, B. (1996) Hegemonic Stability Theory and Economic Analysis: Reflections on Financial Instability and the Need for an International Lender of Last Resort Center for International and Development Economics Research. Working Paper C96-080.

Eichengreen, B. (2014) The Eurozone Crisis: The Theory of Optimum Currency Areas Bites Back, Notenstein Academy White Paper

European Commission (2011a) The Economic Adjustment Programme for Greece. Fourth Review - Spring 2011,

European Commission (2011b), "The Economic Adjustment Programme for Portugal", European Economy Occasional Paper No. 79

European Commission (2014a) The Second Economic Adjustment Programme for Greece Fourth Review, European Economy Occasional Papers 192

European Commission (2014b) The Economic Adjustment Programme for Portugal Eleventh Review, European Economy Occasional Papers 191

European Commission (2014c) Spain — Post Programme Surveillance Autumn 2014 Report European Economy Occasional Papers 206

Rodríguez, F.C. J. and Lucio, M. (2013) Narratives, Myths and Prejudice in Understanding Employment Systems: The Case of Rigidities, Dismissals and the Question of Flexibility in Spain, Economic and Industrial Democracy, 34:2: 310-333

Grahl, J. (2000) Money as Sovereignty: The Economics of Michel Aglietta. New Political Economy, 5: 2: 291-316.

Grahl, J. (2015) "Ein Elephant im Porzelanladen: Germany and the Eurozone", in Wilfried Kurtzke and Gunter Quaisser (eds) Alternative Wirtschafts politik: Festschrift für Axel Troost, BdWi-Verlag, Marburg 
Gowa, J. (1989) Rational Hegemons, Excludable Goods, and Small Groups: An Epitaph for Hegemonic Stability Theory? World Politics 41: 2: 307-24

Hacker, B (2011), Contours of a Political Union - Recalibrating European Economic and Monetary Union through more Integration, Berlin: Friedrich Ebert Stiftung

Hall P., (2016), Varieties of Capitalism in Light of the Euro Crisis, paper presented at the Annual Meeting of the American Political Science Association, Philadelphia, August 2016

Hassel, A. (2014) Adjustments in the Eurozone: Varieties of Capitalism and the Crisis in Southern Europe. LEQS Working Paper No. 76, May 2014

Hassel. A. (2015), Letter from Berlin, The Political Quarterly 86: 1: 7-8

Hooghe L. and Marks, G. (2009) A Postfunctionalist Theory of European Integration: From Permissive Consensus to Constraining Dissensus', British Journal of Political Science, 39: 1: $1-23$

ILO, (2015) Global Wage Report 2014/15, ILO, Geneva

Ioannou, C. (2012) Recasting Greek Industrial Relations: Internal Devaluation in Light of the Economic Crisis and European Integration, International Journal of Comparative Labour Law and Industrial Relations, 28(2): 199-222.

Ioannou, C. and Papadimitriou, K. (2013) Collective Negotiations in Greece during 20112012: Trends, Changes and Prospects, Athens: OMED

Iversen, T. and Soskice D. (2013) A Structural-Institutional Explanation of the Eurozone Crisis. Unpublished manuscript. Cambridge, MA: Harvard University, Department of Government

Iversen, T., Soskice, D. and Hope, A. (2016) 'The Eurozone and Political Economic Institutions', Annual Review of Political Science 19: 163-85

Jacoby W. (2014) The Politics of the Eurozone Crisis: Two Puzzles behind the German Consensus, German Politics \& Society Vol 32: 2: 70-89

Joseph, J. (2002) Hegemony: A Realist Analysis. London: Routledge

Karamessini, M. (2015) "Greece as an international test-case: economic adjustment through a Troika/state-induced depression and social catastrophe" in Lehndorff, S. (ed) Divisive integration: the triumph of failed ideas in Europe - revisited, ETUI, Brussels

Kindleberger, Charles (1973) The World in Depression, 1929-39, Berkeley: University of California Press

Knuth, M. (2014) "Rosige Zeiten am Arbeitsmarkt? Strukturreformen und Beschäftigungswunder" WISO Discussion Paper, Friedrich-Ebert Stiftung, July 
Koukiadaki, A. and Kretsos, L. (2012) Opening Pandora's Box: The Sovereign Debt Crisis and Labour Regulation in Greece, Industrial Law Journal 41(3): 276-304.

Koukiadaki, A. and Kokkinou (2014) The Impact of the Labour Market Reforms on Collective Bargaining in Manufacturing: The case of Greece, national report.

Krugman, P. (2013) 'Revenge of the Optimum Currency Area'. NBER Macroeconomics Annual 2012, 27: 439-48

Lehndorff, S. (2015) Model or liability? The new career of the 'German model' in S. Lehndorff (ed.) Divisive integration: the triumph of failed ideas in Europe - revisited, ETUI, Brussels

Paul Marginson (2015) Coordinated bargaining in Europe: From incremental corrosion to frontal assault? European Journal of Industrial Relations June 21: 2: 97-114

Milner, H. (1998) International Political Economy: Beyond Hegemonic Stability Foreign Policy, 110: 1: 112-123

Molina, O. and Miguélez, F. (2013) From negotiation to imposition: social dialogue in austerity times. ILO Working Paper 51. Geneva: International Labour Office

Moloney, Niamh (2014) European Banking Union: assessing its risks and resilience. Common Market Law Review, Vol 51: 6: 1609-1670

Moravcsik A and Schimmelfennig F., (2009) Liberal Intergovernmentalism in A. Wiener and T. Diez, (eds.) European Integration Theory 2nd ed. Oxford: Oxford University Press

Newman, A. (2015), The Reluctant Leader: Germany's Euro Experience and the Long Shadow of Unification in M. Blyth and M. Matthias (eds) The Future of the Euro, Oxford: Oxford University Press

Notre Europe, (2012) Completing the Euro: A Road Map toward Fiscal Union in Europe. Report of the "Tommaso Padoa Schioppa Group". Paris: Notre Europe - Institut Jacques Delors.

Offe, C. (2014), Europe Entrapped, Polity Press, Cambridge

OECD, (2013), The 2012 Labour Market Reform in Spain: A preliminary Assessment, OECD, Paris

OECD, (2014a), Economic Survey of Portugal 2014, OECD, Paris

OECD, (2014b), Economic Survey of Spain 2014, OECD, Paris

Ramalho P and do Rosário M. (2013), Portuguese labour law and industrial relations during the crisis, ILO GOVERNANCE Working Paper No.54, International Labour Office, Governance and Tripartism Department. Geneva 
Papadimitriou G. (2013) The Greek labour law face to the crisis: A dangerous passage towards a new juridical nature, European Labour Law Network Working Paper 3/2013

Paterson, W. (2011) The Reluctant Hegemon? Germany Moves Centre Stage in the European Union, Journal of Common Market Studies, Vol. 39: annual review: 57-75

Patra, E. (2012) Social Dialogue and Collective Bargaining in Times of Crisis: The Case of Greece, ILO Industrial and Employment Relations Department Working Paper No. 38. Geneva.

Picot G and Tassinari A (2014) Liberalization, dualization, or recalibration? Labor market reforms under austerity, Italy and Spain 2010-20121, Nuffield College Working Paper in Politics

Portugal, P. (2006) Wage setting in the Portuguese labor market: A microeconomic approach, Economic Bulletin, Banco de Portugal

Regan A. and Brazys S. (2015) This Little PIIGS Go to the Market: Ireland and Divergent Recovery in the Eurozone Council for European Studies

Roche, W.K. (2014) HRM in the Recession: managing People in the Private and Public Sectors in Harney, B. and Monks, K (eds). Strategic HRM: Research and Practice in Ireland. Dublin: Orpen Press

Roche, W.K.,Teague, P., Coughlan, A. and Fahy, M. (2013) Recession at Work: HRM in the Irish Crisis. London: Routledge.

Roche, W.K.,Teague, P., Coughlan, A. (2015) Employers, trade unions and concession bargaining in the Irish recession, Economic and Industrial Democracy, early view

Sabel, C. and Jonathan Zeitlin (2012) Experimentalism in the EU: Common ground and persistent differences, Regulation \& Governance, 6: 3: 410 - 426.

Scharpf, F. (2013) Political Legitimacy in a Non-optimal Currency Area, MPIfG Discussion Paper 13/15. Cologne: Max Planck Institute for the Study of Societies.

Scharpf, F. (2014) No Exit from the Euro-Rescuing Trap? MPIfG Discussion Paper 14/4. Cologne: Max Planck Institute for the Study of Societies.

Schäuble W. (2011) A Comprehensive Strategy for the Stabilization of the Economic and Monetary Union, Speech to the Brussels Economic Forum http://ec.europa.eu/economy_finance/bef2011/media/files/speech-brussels-economic-forumschauble.pdf

Schulten, T. and Müller, T. (2014), European economic governance and its intervention in national wage development and collective bargaining in Lehndorff, S. (ed.), Divisive integration: The triumph of failed ideas in Europe, Brussels: ETUI, 331-363.

Sinn, H.-W. (2005) Ist Deutschland noch zu retten? Ullstein Verlag, Berlin 
Sinn, H.-W. (2013) Austerity, Growth and Inflation: Remarks on the Eurozone's Unresolved Competitiveness Problem. CESifo Working Paper No. 4086. Munich: Center for Economic Research search \& Ifo Institute

Schmidt, S. (2007) Mutual Recognition as a New Mode of Governance Journal of European Public Policy, 14: 5: 667 - 681

Snidal, D. (1985) The limits of hegemonic stability theory International Organization 39: 4: 579-614

Streeck, W. (2014) Buying Time: The Delayed Crisis of Democratic Capitalism. London: Verso

Streeck, W. and Elsässer, L. (2014) Monetary Disunion: The Domestic Politics of Euroland. MPIfG Discussion Paper 14/17. Cologne: Max Planck Institute for the Study of Societies. Tsoukalis, L. (2012), Steering Europe out of the Crisis, London: Policy Network.

Távora, I. and González, P. (2014), The Reform of Joint Regulation and Labour Market Policy during the Current Crisis: Portugal National Report for Portugal, EU Commission, Employment, Social Affairs and Inclusion DG 'Industrial Relations and Social Dialogue' Programme

Teague, P and Donaghey, J, (2015) The Life and Death of Irish Social Partnership: Lessons for Social Pacts Business History 57: 3: 418-437

Turrini, A. (2011), "EPL Reforms in Europe: A Portuguese Way to Single Contract Outcomes? Vox, 10 August 2011

Voskeritsian H. and Kornelakis A. (2011) Institutional Change in Greek Industrial Relations in an Era of Fiscal Crisis GreeSE Paper No.52 Hellenic Observatory Papers on Greece and east Europe, London School of Economics

Young, B. and Semmler, W. (2011) The European sovereign debt crisis: Is Germany to blame? German Politics and Society, 29: 1: 1-24 


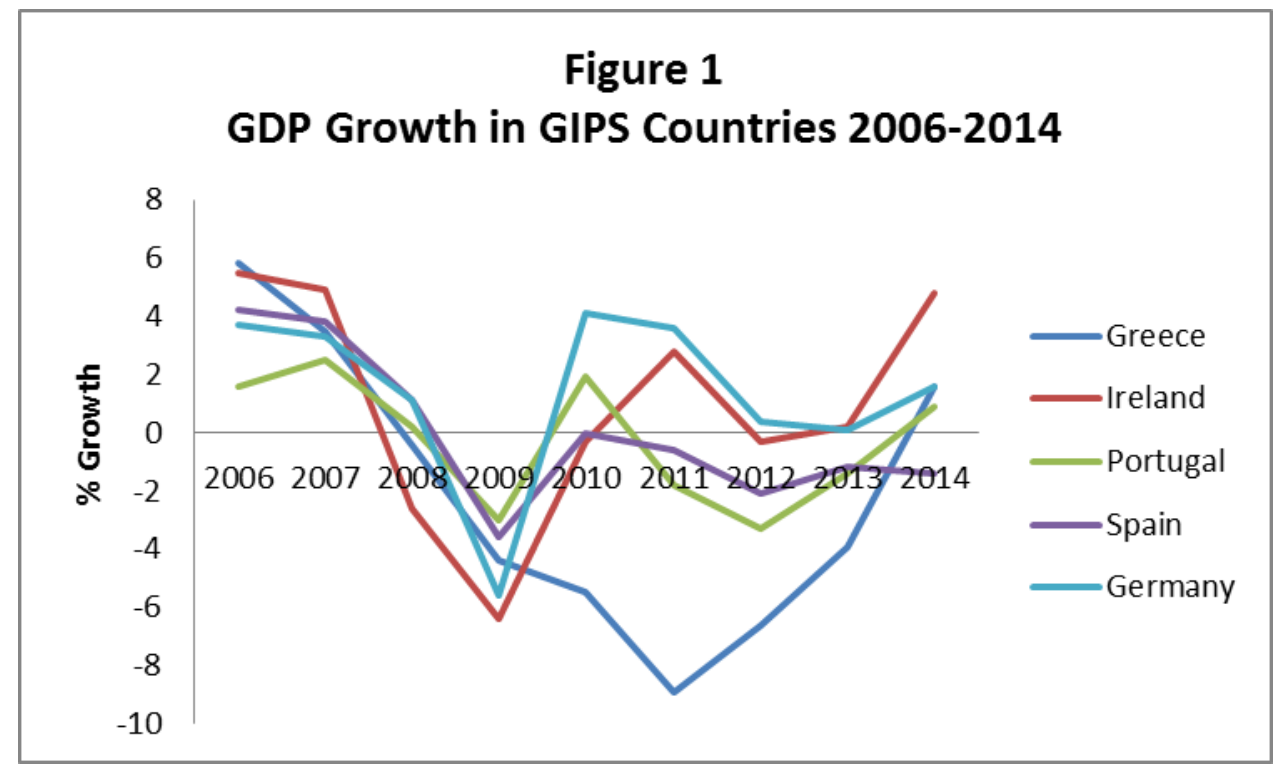


Figure 2 Unit Labour Costs in GIPS countries 1998-2014

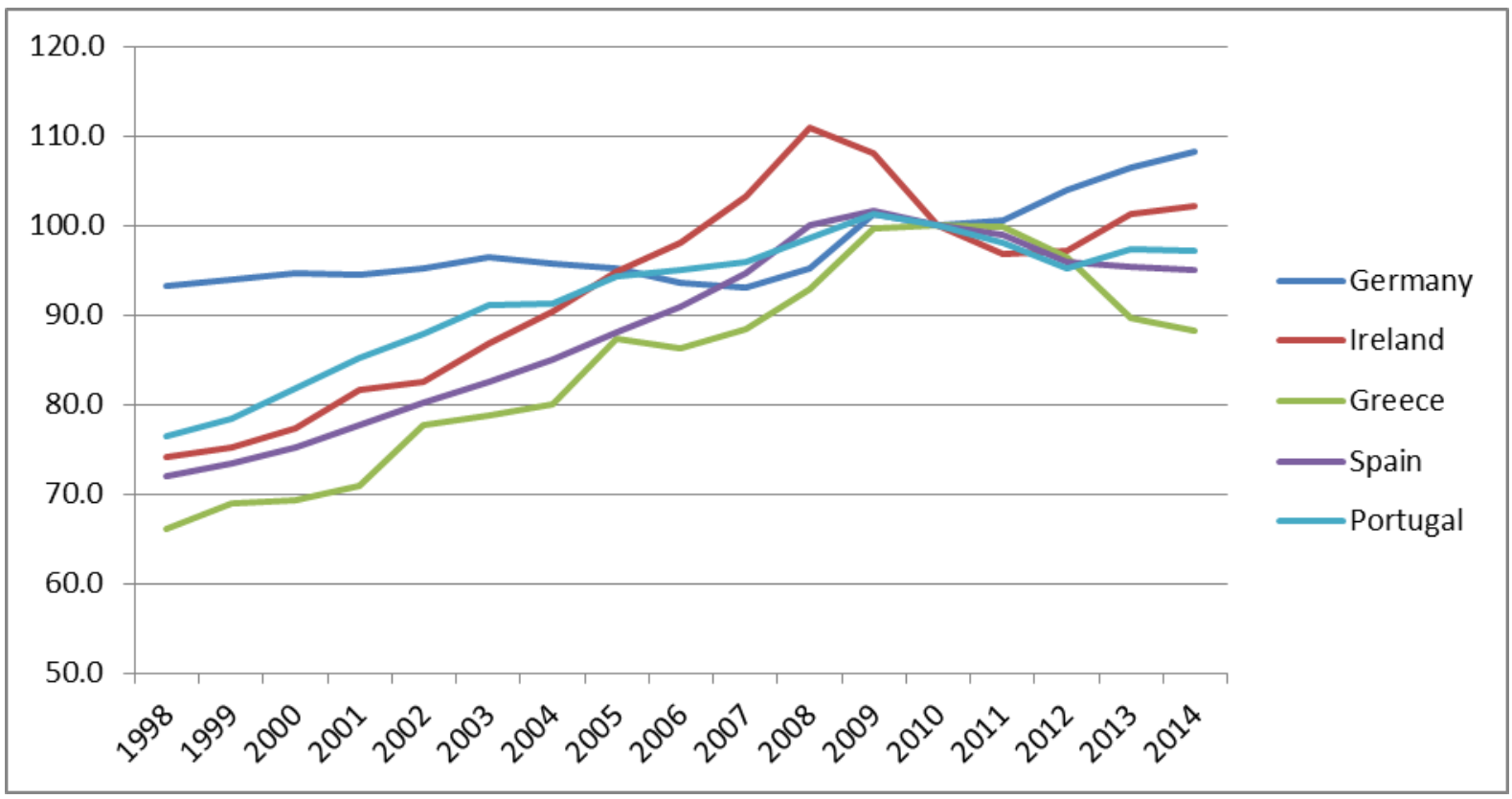

Figure 3: General government gross debt (as \% of GDP) in GIPS countries 2006-2013

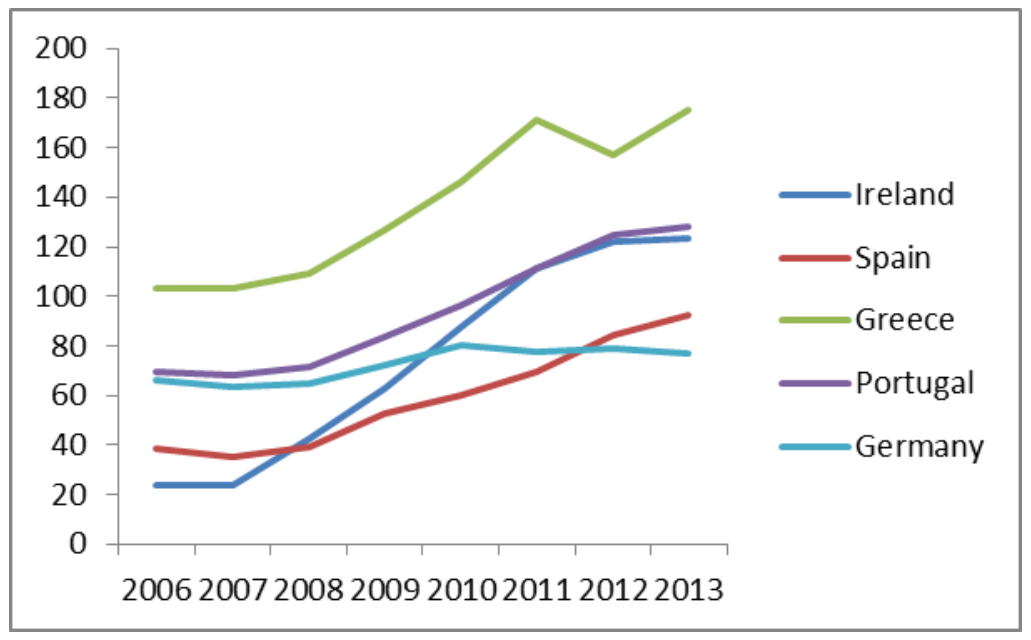


